\title{
Analysis of Offshore Structure Having Different Bracing Pattern Using Sap2000
}

\author{
Neeta Chavhan ${ }^{1 *}$, Bhalge $\mathrm{PS}^{2}$ and Vaidkar $\mathrm{NS}^{3}$ \\ ${ }^{1}$ Professor and $P G$ Student, India \\ ${ }^{2}$ Hod, Department of Civil Engineering, India \\ ${ }^{3}$ Prof., Department of Civil Engineering, India \\ Submission: July 12, 2019; Published: August 12, 2019 \\ *Corresponding author: Neeta Chavhan, Professor and PG student, SYCET, Aurangabad, India
}

\begin{abstract}
In this paper time history analysis is performed for offshore steel structures for El-Centro data for 31sec. The effect of slope (different angle 0degree, $20 \mathrm{degree}$ and 30degree) is studied for various loading condition and the effect bracings (single bracings, knee bracings, cross bracings) for different loading are also studied. For FEA analysis SAP 2000 is used which observed very effective for analysis.
\end{abstract}

Keywords: Offshore structure; SAP 2000; El-Centro; Bracings

\section{Introduction}

The total number of offshore platform in various bays, gulf and oceans of the world is increasing year by year, most of which are of fixed jacket-type platforms located in $30 \mathrm{~m}$ to $200 \mathrm{~m}$ depth for oil and gas exploration purposes [1]. Fixed offshore platforms are subjected to different environmental loads during their lifetime. These loads are imposed on platforms through natural phenomena such as wind, current, wave, earthquake, snow and earth movement. Among various types of environmental loading, wave forces loading is dominated loads [2]. The results of these investigations highlight the importance of accurately simulating nonlinear effects in fixed offshore structures from the point of view of safe design and operation of such systems. It is necessary to design an offshore structure such that it can respond to moderate environmental loads without damage and is capable of resisting severe environmental loads without seriously endangering the occupants [3-5]. The standard design of the structure is carried out using the allowable stress method. However, it is important to clarify the effects on nonlinear responses for an offshore structure under the severe wave conditions. Offshore structures may be analyzed using static or dynamic analysis methods. Static analysis methods are sufficient for structures, which are rigid enough to neglect the dynamic forces associated with the motion under the time-dependent environmental loadings [6-9]. On the other hand, structures which are flexible due to their particular form and which are to be used in deep sea must be checked for dynamic loads.

\section{Methodology}

The main objective of this study is to examine the behavior of Off-shore structure with different bracing system with different angles provided to structure.

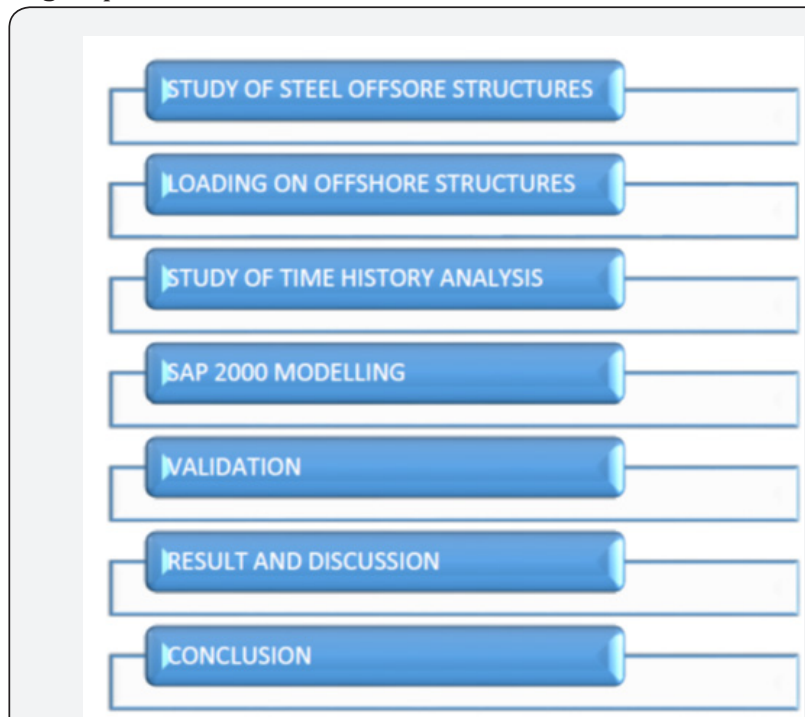

Figure 1: Procedure.

Single bracing for $0^{\circ}$ structure

a) Double bracing for $0^{\circ}$ structure

b) Knee bracing for $0^{\circ}$ structure 
c) Single bracing for $20^{\circ}$ structure

d) Double bracing for $20^{\circ}$ structure

e) Knee bracing for $20^{\circ}$ structure

f) Single bracing for $30^{\circ}$ structure

g) Double bracing for $30^{\circ}$ structure

h) Knee bracing for $20^{\circ}$ structure

All above cases are analyzed for time history analysis Figure 1. The analysis is carried out using SAP 2000 software. The comparison is made between different bracing systems. They study of platform is a fixed Jacket-Type platform currently installed in the Suez gulf [7].

\section{Response Spectrum Method}

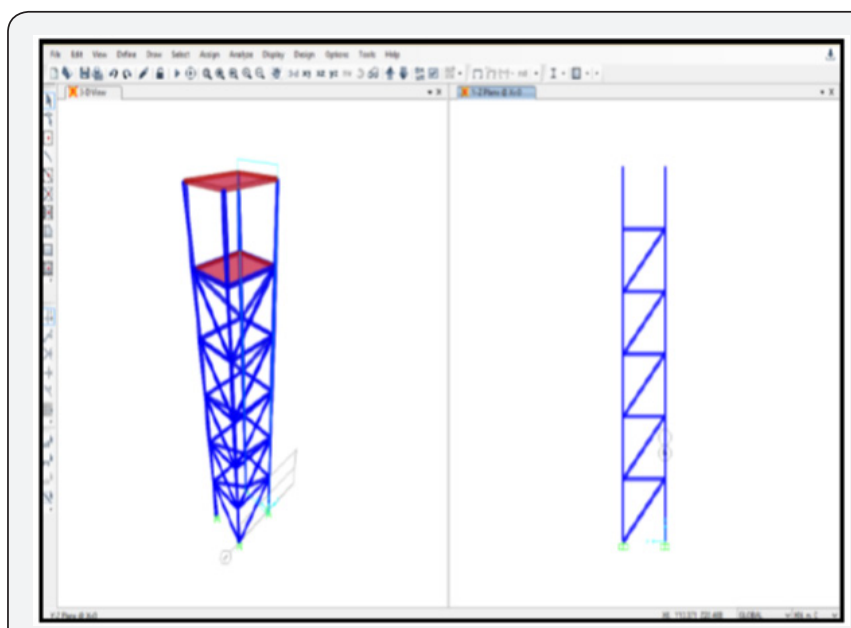

Figure 2: Single Bracing 0 Degree.

Response spectrum analysis is a procedure for computing the statistical maximum response of a structure to a base excitation Figure 2. Each of the shaking modes that are considered may be assumed to respond independently as a single-degreeof-freedom system [10]. Spectra which determine the base acceleration applied to each mode according to its period (the number of seconds required for a cycle of vibration).

\section{Ground Motions and Linear Time History Analysis}

The time history analysis calculates the building responses at discrete time steps using discretized record of synthetic time history as base motion [11]. If three or more-time history analyses are performed, only the maximum responses of the parameter of interest are selected.

\section{Problem Statement}

The studied platform is a fixed Jacket-Type platform currently installed in the Suez gulf, Red sea, 1988 shown in Figure 3, The offshore structure is a four legs jacket platform, consists of a steel tubular-space frame [12-14]. There are diagonal brace members in both vertical and horizontal planes in the units to enhance the structural stiffness [15-17].

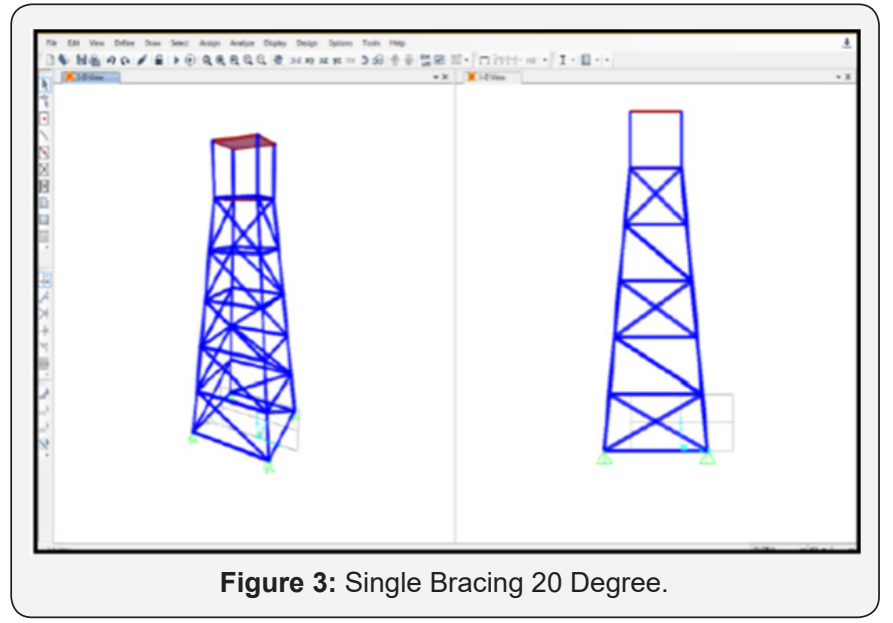

The Platform was originally designed as a 4-pile platform installed in 110 feet $\left(110^{\prime}=33.5 \mathrm{~m}\right)$ water depth.
a. $\quad$ Outer diameter $0.762 \mathrm{~m}$
b. Inner diameter $0.664 \mathrm{~m}$
c. Wall thickness for platform $0.05 \mathrm{~m}$
d. Spacing of horizontal member $5.6 \mathrm{~m}$
e. X-braced with tubular member diameter $0.32 \mathrm{~m}$
f. Density of various materials considered for design,
g. Concrete $-25 \mathrm{kN} / \mathrm{m}^{3}$
h. Insulation $-1 \mathrm{kN} / \mathrm{m}^{3}$
i. Structural steel $-78.5 \mathrm{kN} / \mathrm{m}^{3}$

\section{SAP2000 Software Model}

in this we compared the single system bracing system in different degree that is (0degree, 20degree, 30 degree) and we come to know that 30 degree model is preferable to the forces applied in time history Table 1.

Table 1: Proposed models in SAP 2000.

\begin{tabular}{|c|c|}
\hline \multicolumn{2}{|c|}{ Proposed Models in SAP 2000 } \\
\hline MODEL NO.1 & OFFSHORE PLATFORM WITH SINGLE BRACING 0 DEGREE \\
\hline MODEL NO.2 & OFFSHORE PLATFORM WITH DOUBLE BRACING 0 \\
DEGREE
\end{tabular}


Result and Discussion
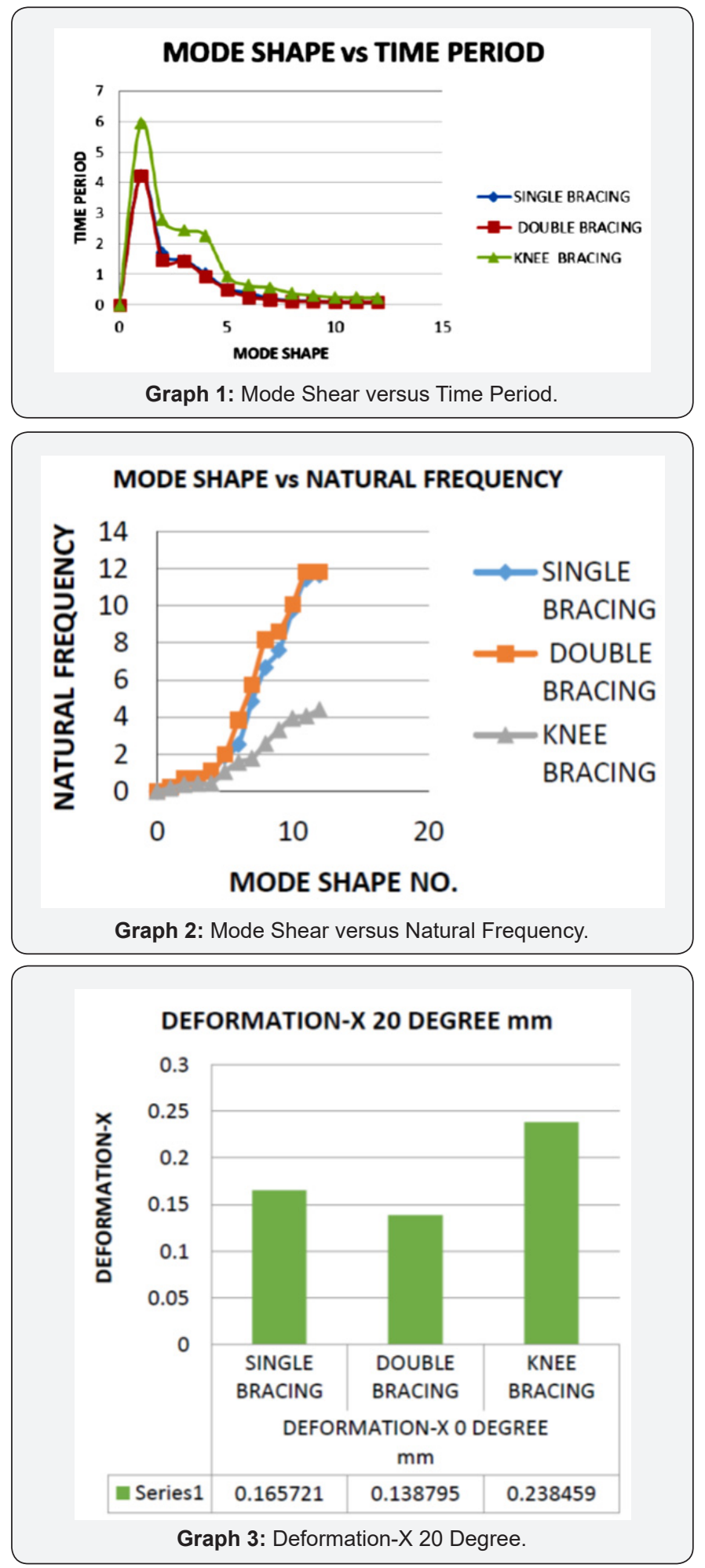

i. In this Graph 1 Mode Shear vs Time Period highest time period is observed $(6.1 \mathrm{sec}$.) for knee bracing.

ii. In this Graph 2 Mode Shear vs Natural Frequency highest natural frequency $(14 \mathrm{~Hz})$ is observed for double bracing.

iii. In this Graph 3 Deformation-x20 Degree Highest deformation is observed $0.24 \mathrm{~mm}$ for single bracing. Therefore, double bracing is most effective as compared to single and knee bracing

iv. In this Graph $40.6 \mathrm{~mm}$ highest deformation is observed for single bracing Therefore double bracing is most effective as compared to single and knee bracing

v. In this Graph 5 Base shear $295 \mathrm{kN}$ for o degree highest base shear is observed for single bracing Therefore double bracing is most effective as compared to single and knee bracing due to less deformation.
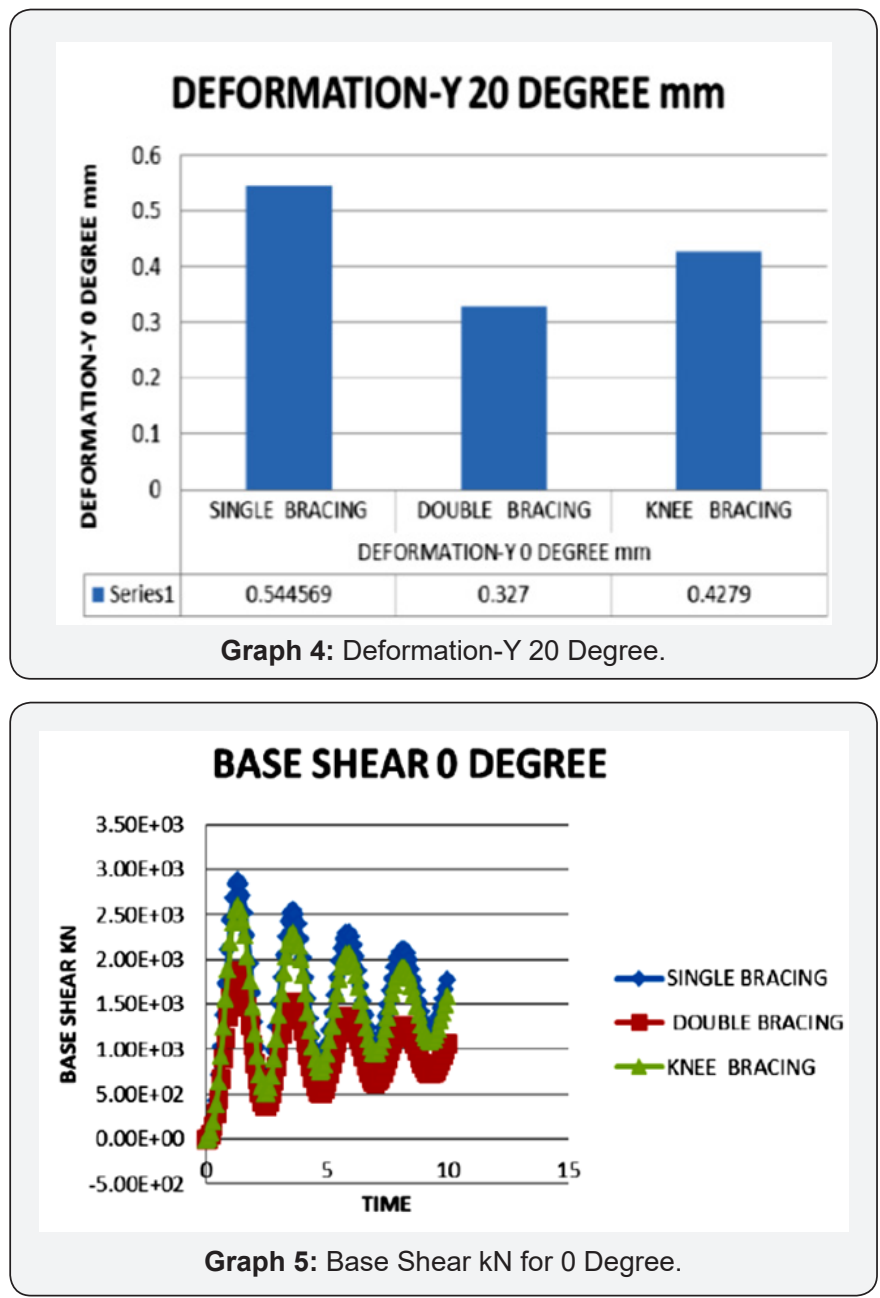

\section{Conclusion}

In this paper, various types of bracings are studied subjected to dynamic load and it is observed that deformation in y direction is $25 \%$ less in double bracing and $15 \%$ less in knee bracing. But deformation in $\mathrm{X}$ direction is observed more in knee bracings. In addition to this, the natural frequency is observed more in knee bracings. For base shear, it is observed that base shear is $15 \%$ more in single bracings than the cross bracings and knee bracings.

\section{References}

1. Shehata E Abdel Raheem, Elsayed MA Abdel Aal, Aly GA Abdel Shafy, Fayez K Abdel Seed (2012) Nonlinear Analysis of Offshore Structures under Wave Loadings. $15^{\text {th }}$ conference WCEE LISBOA pp. 1-10. 


\section{Civil Engineering Research Journal}

2. API RP 2A - WSD (2000) Recommended Practice for Planning, Designing and Constructing Fixed Offshore Platforms - Working Stress Design, (21 $1^{\text {st }}$ edn), USA.

3. API (American Petroleum Institute) (1993) recommended practice RP 2A-LRFD - Load Resistance Factor Design - $\left(1^{\text {st }}\right.$ edn), for design of offshore structures, USA.

4. Det Norske Veritas (DNV) Result for the Design, Construction and Inspection of Offshore Structures. Oslo.

5. Barltrop ND, Adams AJ (1991) Dynamics of Fixed Marine Structures, ( $3^{\text {rd }}$ edn), Marine Technology Directorate Limited, Epsom, UK.

6. CIRIA (1977) Dynamics of Fixed Marine Structures, methods of calculating the dynamic response of fixed structures subjected to wave and current action, Underwater Engineering Group report, UR8, UK.

7. Schueller GI (1988) What is reliability? Structural Safety and Reliability $1: 3-35$.

8. Chakarabarti SK, Tam A (1975) Interaction of waves with large vertical cylinder. Journal of Ship Research 19: 22-23.

9. Raman H, Jothishankar H, Venkatanarasaiah P (1977) Nonlinear wave interaction with vertical cylinder of large diameter. Journal of Ship Research 21(1): 120-124.

10. Zhu S (1973) Diffraction of short-crested waves around a circular cylinder. Ocean Engineering 20(4): 389-407.

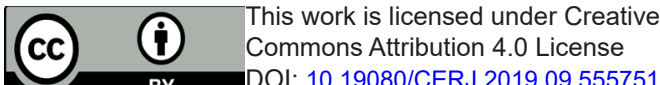
Commons Attribution 4.0 License
11.Zhu S, Moule G (1994) Numerical calculation of forces induced by short-crested waves on a vertical cylinder of arbitrary cross-section. Ocean Engineering 21(7): 645-662.

12. Harish N, Sukomal M, Shanthala B, Subba R (2010) Analysis of offshore jacket platform, Natl. Conf. on Sustainable Water Resources Management - SWaRM 20; NITK, Surathkal; India, p. 7-9.

13. Nagamani K, Ganapathy C (1996) Finite element analysis of nonlinear dynamic response of articulated towers. Computers \&Structures 59(2): 213-223.

14. James F. Wilson (2002) Dynamics of Offshore Structures, Technology pp. 344 .

15. Engin GR, Tugru E, Umit G (2011) Effect of Changes on Joint Connections of Steel Lattice Towers due to Environmental Loads. International Journal of Engineering and Industries 2(1): 30-37.

16. Jain AK (1996) Dynamics of offshore structures under sea waves and earthquake forces, American Society of Mechanical Engineers. Offshore Technology 1: 191-198.

17. Fayed M, Shehab M, Zidan M, Harb M (2005) Dynamic response of fixed offshore structures under environmental loads, Eleventh Internationa Colloquium on Structural and Geotechnical Engineering, $11^{\text {th }}$ ICSGE, Cairo - Egypt, E05SR26 p. 1-16.

\section{Your next submission with Juniper Publishers will reach you the below assets}

- Quality Editorial service

- Swift Peer Review

- Reprints availability

- E-prints Service

- Manuscript Podcast for convenient understanding

- Global attainment for your research

- Manuscript accessibility in different formats

( Pdf, E-pub, Full Text, Audio)

- Unceasing customer service

Track the below URL for one-step submission https://juniperpublishers.com/online-submission.php 